\title{
STUDY PENGARUH SUHU DAN TEKANAN UDARA TERHADAP OPERASI PENERBANGAN DI BANDARA H.A.S. HANANJOEDDIN BULUH TUMBANG BELITUNG PERIODE 1980-2010
}

\author{
Akhmad Fadholi \\ akhmad.fadholi@bmkg.go.id \\ Staff Analisa Cuaca \\ Stasiun Meteorologi Depati Amir Pangkalpinang
}

\begin{abstract}
Abstrak
Dalam operasi penerbangan ada tiga tingkat (fase) yang sangat penting dan berhubungan dengan meteorology yaitu lepas landas (take off), penerbangan, dan mendarat (landing). Dalam hal ini sejumlah unsur meteorologi dapat berpengaruh terhadap kemampuan pesawat terbang pada saat-saat kritis. Diantara unsur yang dapat menunjang kelancaran ketiga fase di atas adalah suhu dan tekanan udara, dimana unsur cuaca tersebut harus dimengerti dan diperhitungkan yang selanjutnya akan menentukan kerapatan udaranya dan selanjutnya akan menentukan daya angkat pesawat terbang. Menggunakan metode regresi linier sederhana trend suhu maksimum tahun 1980-2010 di Bandara Hananjoeddin Belitung cenderung naik $1,17^{\circ}$ dan tekanan udara cenderung turun $0,47^{\circ} \mathrm{C}$. Menggunakan rumus density height didapatkan nilai terendah tahun 1988 sebesar 1878,39 feet dan tertinggi tahun 2006 sebesar 2118,22 feet. Hasil penelitian ini dipandang perlu untuk mengetahui mengenai pengaruh unsur cuaca khususnya bagi dunia penerbangan sehingga ICAO (International Civil Aviation Organization) membuat satuan standar yang diperuntukkan bagi pelayanan dan keselamatan penerbangan.
\end{abstract}

Kata kunci: penerbangan, suhu, tekanan udara, density height.

\begin{abstract}
There are three levels of operation in aviation, it is very important and related to meteorology that is take off, flight, and landing. In this case, meteorological elements influence the ability of the aircraft at critical moments. Among the elements, the temperature and air pressure must be understood and taken into account in order to find lift value of aircraft. Using linier regression method, maximum temperature tend in Hananjoeddin Belitung Airport in 1980-2010 rise up to $1,17^{\circ} \mathrm{C}$ and air pressure trend down to $0,47 \mathrm{mb}$. Using density height formula, the lowest value is 1878,39 feet in 1988 and the highest is 2118,22 feet in 2006. The result of this research is very important to know about the effect of weather elements. Especially for aviation, ICAO (International Civil Aviation Organization) made the standard units dedicated to service and flight safety.
\end{abstract}

Keyword: flight, temperature, air pressure, density height 


\section{PENDAHULUAN}

Penerbangan secara keseluruhan selalu memperhatikan keselamatan penerbangan, keteraturan dari penerbangan dan efisiensi atau kenyamanan penerbangan. Tetapi pada kenyataannya hal-hal tersebut selalu menghadapi hambatan atau gangguan baik secara teknis maupun secara meteorologi. Gangguan secara meteorologi pengaruh dari unsur cuaca selalu mendapatkan perhatian yang khusus bagi dunia penerbangan [1]. Hal ini terutama pada saat pesawat akan mengudara (take off) maupun pada saat mendarat (landing). Karena hal ini akan mempengaruhi gaya angkat dari pesawat itu sendiri.

Dalam praktek unsur cuaca misalnya pola suhu udara dan tekanan udara berbeda untuk setiap tempat (bervariasi). Tekanan dan suhu disuatu tempat selalu berubah bersama dengan perubahan waktu. Dengan mengetahui gangguan unsur cuaca pada saat pesawat akan mengudara (take off) dan mendarat (landing), maka gangguan tersebut akan dapat diantisipasi sehingga pesawat akan terhindar dari kecelakaan.

Suhu dan tekanan udara merupakan unsur cuaca yang vital bagi operasi penerbangan. Kondisi suhu dan tekanan udara di suatu bandara sangat berpengaruh terutama pada saat take off dan landing. Dengan perhitungan suhu udara mkasimum dan tekanan udara akan dihasilkan nilai density height yang akan membantu operator penerbangan dalam mengambil tindakan saat take off atau landing tersebut.

Pengalaman memberikan gambaran yang nyata bahwa kecelakaan pesawat sering terjadi dikarenakan adanya gangguan dari unsur cuaca terutama pada saat pesawat melakukan pendaratan. Gangguan cuaca yang terjadi merupakan suatu hal yang alamiah dan tidak dapat dielakan lagi. Untuk itu diharapkan agar penerbang mengenal betul karakteristik keadaan cuaca pada suatu bandara tertentu, sehingga membutuhkan pelayanan meteorologi yang akurat dan berkesinambungan. Tujuan penulisan ini adalah untuk memberikan gambaran yang jelas mengenai pengaruh unsur cuaca khususnya suhu dan tekanan udara terhadap operasi penerbangan.

\section{KAJIAN TEORI}

\subsection{Unsur Cuaca dan Operasi Penerba- ngan}

Meteorologi adalah cabang ilmu yang mempelajari keadaan atmosfer dari suatu tempat dan mempunyai hubungan erat serta merupakan faktor penunjang dalam proses penerbangan. Klimatologi merupakan kajian ilmiah yang membahas tentang penganalisaan unsur cuaca seperti temperatur, tekanan udara dan lain sebagainya. Hal ini dilakukan untuk menentukan keadaan cuaca atau iklim suatu daerah tertentu dan mamperhatikan keadaan cuaca yang akan datang.

Didalam operasi penerbangan terdapat tiga tahap kegiatan pokok sebagai berikut [2]:

a. Lepas landas (Take off)

b. Dalam penerbangan

c. Mendarat (Landing)

Untuk melaksanakan ketiga tahap kegiatan tersebut termasuk didalamnya keperluankeperluan akan informasi meteorologi permukaan yang diamati pada area lapangan terbang yang bersangkutan. Dari ketiga tahap di atas, tahap pendaratan merupakan tahap yang paling penting. Meskipun pesawat-pesawat modern sudah mampu mengudara dan terbang dalam keadaan cuaca yang kurang baik, tetapi didalam keadaan yang sama kemampuan tersebut masih belum dapat dicapai pada saat pendaratan.

Oleh karena itu informasi meteorologi yang diperlukan untuk tahap pendaratan sama dengan yang diperlukan pada saat lepas landas, maka di bawah ini akan diutarakan unsur cuaca yang mana dalam penulisan ini dibatasi hanya temperatur udara dan tekanan udara yang mempunyai makna penting dalam penerbangan pada saat take off dan landing. 


\subsection{Suhu Udara}

Temperatur adalah suatu ukuran untuk tingkat panas suatu benda. Suhu suatu benda ialah keadaan yang menentukan kemampuan benda tersebut untuk mentransfer panas atau menerima panas, dari benda satu ke benda yang lain. Distribusi suhu di dalam atmosfer sangat bergantung terutama pada keadaan radiasi matahari, oleh sebab itu suhu udara selalu mengalami perubahan [3].

Temperatur udara permukaan bumi merupakan salah satu unsur penting yang diamati oleh pengamat cuaca (Meteorological Station maupun Climatological Station). Dalam meteorologi yang dimaksud dengan suhu udara permukaan adalah suhu udara pada ketinggian 1.25 sampai dengan 2 meter dari permukaan tanah.

Suhu udara adalah salah satu faktor penting terhadap daya kerja pesawat terbang. Pada suatu tekanan udara dalam suhu yang tinggi akan mengakibatkan rendahnya kerapatan udara, dimana akan menimbulkan pengaruh yang meragukan pesawat-pesawat terbang terutama pada saat mengudara. Diketahuinya suhu udara oleh penerbang memungkinkan baginya untuk:

a. Menentukan Efisiensi penggunaan mesin sehubungan dengan diketahuinya tekanan udara, maka dapat diketahui daya kerja pesawat yang seharusnya pada saat mengudara atau mendarat, yang sekaligus dapat menentukan berapa panjangnya landasan yang harus digunakan sesuai dengan berat muatan pesawat.

b. Menentukan apakah ada kemungkinan terjadinya pengendapan es pada pesawat. Dengan diketahuinya struktur awan dan keadaan suhu udara pada lapisan-lapisan di atas permukaan tanah, maka suhu permukaan dapat digunakan untuk mencari tanda-tanda endapan es pada pesawat.

Suhu udara berbanding terbalik dengan kerapatan udaranya [4]. Pada lapisan troposfer dimana suhu menurun terhadap ketinggian maka besarnya kerapatan udara berbeda untuk setiap ketinggian (level). Hal itu selalu diperhatikan dalam operasi penerbangan , terutama erat kaitannya dengan gaya angkat (Lift) yang dihasilkan oleh pesawat pada lapisan tertentu dari atmosfer. Selain itu untuk keperluan take off dan landing, maka informasi suhu udara pada ketinggian 3 meter merupakan informasi pada engine level dimana mempunyai pengaruh terhadap efisiensi mesin pesawat yang telah diutarakan diatas [5].

\subsection{Tekanan Udara}

Tekanan menggambarkan gaya per satuan luas pada suatu ketinggian tertentu. Dimana tekanan udara merupakan salah satu faktor yang mempengaruhi dan menentukan kerapatan udara selain daripada suhu udara.

Ketinggian kerapatan udara (density height) adalah suatu ketinggian dalam atmosfer standar ICAO, dimana kerapatan udaranya sesuai dengan kerapatan udara pada suatu tempat tertentu. Pengertian ini sangat berguna dalam menentukan karakteristik daya kerja pesawat terbang dan mesin-mesinnya serta panjang landasan yang digunakan untuk mengudara [4].

Pada umumnya makin tinggi suatu ketinggian dari permukaan laut, tekanan udaranya semakin berkurang, karena jumlah molekul dan atom yang ada di atasnya berkurang. Dengan demikian dapat kita katakana bahwa tekanan udara menurun terhadap ketinggian, begitu juga dengan kerapatan udara. Untuk kegiatan take off dan landing, hal ini kurang menguntungkan karena gaya angkat (Lift) berkurang. Berkurangnya tekanan sekaligus kerapatan udara tersebut di atas, akan mengakibatkan kecepatan pesawat yang lebih tinggi atau landasan yang lebih panjang untuk memperoleh gaya angkat (Lift) yang diperlukan. Dalam kondisi yang sama menurunnya kerapatan udara ini akan juga berarti pengerem (Drag) bagi pesawat yang akan mendarat, sehingga diperlukan landasan yang lebih panjang dari pesawat di 
lapangan terbang yang elevasinya lebih tinggi [6].

Dalam operasi penerbangan internasional dikenal beberapa satuan tekanan udara, yaitu:

$$
\begin{aligned}
1 \text { atmosfer } & =1,03329 \mathrm{~kg} / \mathrm{cm}^{2} \\
& =14,696 \mathrm{Lbs} / \mathrm{Inch}^{2}(\mathrm{psi}) \\
& =760 \mathrm{mmHg} \\
& =1013,25 \mathrm{mb}
\end{aligned}
$$

Di dalam udara sepertihalnya di dalam zat cair, maka pada setiap titik tekanannya akan sama kesegala arah. Hal ini disebabkan karena molekul-molekul dan atom-atom bergerak ke segala arah. Distribusi tekanan horizontal maupun vertical diakibatkan oleh 2 sebab pokok, yaitu:

a. Sebab-sebab thermos

Temperatur udara pada atmosfer mempengaruhi kerapatan atau berat gas pada volume tertentu. Hal ini menyebabkan udara yang mendapatkan panas akan berekspansi dan kerapatannya pun berkurang. Jadi berat kolom udara yang panas lebih ringan jika dibandingkan dengan berat kolom udara yang dingin. Perubahan suhu dan kerapatan udara ini menyebabkan timbulnya gerakan baik secara horizontal maupun vertikal yang mengakibatkan timbulnya perubahan tekanan.

b. Sebab-sebab dinamis

Bumi yang berputar pada porosnya menyebabkan timbulnya gaya-gaya antara lain gaya sentrifugal dan permukaan bumi karena kekasarannya menyebabkan adanya gesekan dengan udara di atasnya. Gaya gesekan ini merupakan hambatan. Gaya gesekan dan gaya sentrifugal secara bersamaan akan menimbulkan gerakan-gerakan udara yang selanjutnya menimbulkan adanya perubahan tekanan.

\subsection{Pengaruh Suhu dan Tekanan Udara terhadap Operasi Penerbangan}

Sebagian besar saat-saat kritis bagi operasi penerbangan adalah waktu lepas landas dan mendarat. Dalam hal ini sejumlah unsur meteorologi dapat berpengaruh terhadap kemampuan pesawat terbang pada saat-saat kritis.

Suhu di lapangan terbang mempunyai peranan penting dalam operasi penerbangan. Diantaranya[7]:

a. Penerbang dapat menentukan kemampuan mesin pesawat untuk dapat digunakan semaksimal mungkin. Atas dasar suhu dan tekanan udara penerbang dapat memperhitungkan beban dan panjang landasan pada waktu take off dan landing

b. Penerbang dapat menentukan density height-nya (ketinggian kerapatan udaranya). Untuk ketinggian $1^{\circ} \mathrm{C}$ dapat menyebabkan kesalahan perhitungan ketinggian 120 feet.

Variasi suhu sekelilingnya sangat berpengaruh terhadap pesawat terbang. Akibat dari kenaikan suhu akan menyebabkan kekurangan arus udara yang dihisap dan kelajuannya, bertambahnya bahan bakar yang digunakan dan kurang efisien bekerjanya kompresor. Karena itu penerbang harus bisa membedakan antara perubahan suhu pada tekanan tertentu dengan perubahan akibat alami bila ketinggian berubah.

Tekanan udara bersama-sama dengan suhu akan menentukan kerapatan udaranya dan selanjutnya akan menentukan kemampuan daya angkat pesawat terbang. Kerapatan dan tekanan udara tergantung dari suhunya maka untuk penentuan ketinggian harus ada juga perhitungannya.

Density height sangat berguna untuk menentukan kamampuan pesawat dan mesinnya, terutama di lapangan yang terletak pada dataran tinggi dimana kecepatan terbang dan panjang landasan sangat kritis. Sebagai contoh suatu lapangan terbang dengan elevasi 1860 feet, tekanan di lapangan $942 \mathrm{mb}$ dengan temperatur $38^{\circ} \mathrm{C}$, maka jika dihitung density heightnya 5229 feet, artinya jika pada keadaan tersebut sebuah pesawat terbang akan mendarat pada lapangan terbang tersebut, maka pesawat yang bersangkutan harus mempunyai 
karakteristik daya kerja yang sama dengan pendaratan dengan elevasi 5229 feet.

\subsection{Hubungan Pengamatan Unsur Cuaca dan Penerbangan}

Terdapat perbedaan yang penting antara pengamatan synoptik dengan pengamatan untuk penerbangan. Pengamatan synoptik bertujuan untuk mendapatkan data unsur meteorologi yang representatif untuk suatu daerah yang agak luas. Sedangkan pengamatan untuk penerbangan bertujuan memperoleh data meteorologi yang representatif di atas suatu daerah yang terbatas, khususnya diatas lapangan terbang yang digunakan pada saat mengudara dan mendarat.

Oleh karena suhu udara mempengaruhi daya kerja pesawat terbang, maka dunia penerbangan harus sangat berkepentingan akan suhu udara. Khususnya suhu udara pada level-level di atas landasan. Karena sukarnya pengamatan suhu udara pada tempat tersebut, maka biasanya digunakan data pengamatan dari Thermometer yang diletakkan pada sangkar meteo. Dengan demikian maka pemilihan letak sangkar meteo menjadi sangat penting untuk memperoleh hasil pengamatan suhu udara, sedekat mungkin dengan syarat yang diharuskan dalam penerbangan. Selanjutnya diadakan penilikan adanya perbedaan yang menyolok antara suhu dalam sangkar dan suhu diatas landasan segera dapat diketahui.

Hubungan antara tekanan dan ketinggian sangat berguna di dalam hal "Altimeter tekanan". Altimeter tekanan adalah alat pengukur tekanan yaitu aneroid barometer, skalanya dibuat untuk menunjukkan satuan ketinggian maupun tekanan udara. Hubungan antara tekanan dan ketinggian tersebut berbeda-beda, tergantung suhu udara permukaan sampai dengan suhu udara pada ketinggian yang bersangkutan dan pada faktor tersebut selalu mengalami perubahan sepanjang ruang dan waktu. Adanya penyimpangan atau perubahan pada keadaan tekanan maupun suhu udara, diperlukan penyetelan terhadap altimeter untuk mendapatkan data ketinggian yang benar.

Tekanan udara yang dipergunakan sebagai patokan dan di setel pada skala tekanan, umumnya dinyatakan dalam bentuk sandi internasional. Adapun sandi tersebut adalah sebagai berikut:

QFE Tekanan udara pada permukaan lapangan terbuka yang didapat dari tekanan yang diamati pada ketinggian induk barometer, kemudian dijabarkan ke tekanan permukaan lapangan terbang.

QFF : Tekanan udara pada suatu stasiun dijabarkan ke tekanan permukaan laut sesuai dengan konvensi meteorologi.

QNE : Ketinggian tekanan (Pressure Height) terhadap tekanan lapangan terbang.

QNH : Tekanan udara pada lapangan terbang dijabarkan ke tekanan permukaan laut sesuai dengan spesifikasi atmosfer standar ICAO.

Dalam praktek operasi penerbangan, jika QFE ini di setel pada skala maka jarum akan menunjukkan ketinggian nol dan ini dipergunakan untuk keperluan landing. Tetapi jika QNH yang kita setel, jarum akan menunjukkan elevasi stasiun pada tempat pendaratan. Umumnya cara ini sering dipergunakan. QNE biasanya dipergunakan dalam hubungannya dengan suhu udara untuk memperoleh ketinggian kerapatan udara (density height) yang merupakan petunjuk yang baik terhadap daya kerja suatu pesawat.

\section{METODOLOGI PENELITIAN}

Data yang digunakan dalam penelitian ini berupa data rata-rata suhu udara maksimum dan tekanan udara Stasiun Meteorologi H.A.S. Hananjoeddin Buluh Tumbang Belitung dengan indikator WIOD yang terletak pada $02^{\circ} 44^{\prime} 42,00^{\prime \prime} \mathrm{LS}$ dan $107^{\circ} 4^{\prime}$ ' 11,01" BT dengan elevasi 164 meter. Data diambil secara bulanan selama periode waktu 31 tahun (1980-2010). 
Metode pengolahan data yang digunakan adalah pembuktian rumus Statistika yaitu Regresi Linier, dimana rumus Regresi Linier dapat digunakan untuk memprediksi keadaan suhu dan tekanan udara yang akan datang. Langkah-langkah yang akan diambil dalam metode ini ialah dengan cara mengumpulkan dan menginventarisir data yang ada, yang telah dicatat pada F Klim 71. F Klim 71 merupakan formulir yang di dalamnya dicatat data-data klimatologi bulanan pada stasiun pengamatan yang bersangkutan. Setelah data dikumpulkan dan diinventarisir dari F Klim 71 dapat diolah dengan menggunakan rumus regresi linear [8] yaitu

$$
\mathbf{Y}=\mathbf{a}+\mathbf{b X}
$$

untuk mengetahui garis trend (kecenderungan) tersebut harus diketahui nilai a dan nilai b-nya yaitu:

$$
\begin{gathered}
\mathrm{a}=\frac{\sum \mathrm{Y}-\mathrm{b} \Sigma \mathrm{X}}{\mathrm{N}} \\
\mathrm{b}=\frac{\mathrm{N} \sum \mathrm{XY}-\Sigma \mathrm{X} \Sigma \mathrm{Y}}{\mathrm{N} \Sigma \mathrm{X}^{2}-\left(\sum \mathrm{X}\right)^{2}}
\end{gathered}
$$

Dimana :

$\mathrm{Y}=$ Trend (kecenderungan) suhu udara atau tekanan udara rata-rata bulanan atau tahunan bulan atau tahun ke $\mathrm{X}$

$A=$ Nilai Trend periode awal yaitu pada saat $\mathrm{X}=0$

$\mathrm{b}=$ Koefisien arah garis trend

$\mathrm{X}=$ Tahun ke...

Untuk mempermudah pengolahan data penulis menggunakan program Excel untuk mendapatkan hasil dari rumus yang ada.

Penulis juga menggunakan perhitungan density height yang melibatkan data ratarata temperatur dan tekanan udara bulanan. density height adalah ketinggian dalam atmosfer standar ICAO (International Civil
Aviation Organization) dimana kerapatan udara sesuai dengan kerapatan udara di suatu tempat tertentu. Density Height sangat penting didalam penerbangan karena dengan diketahuinya kerapatan udara pada lapisan tertentu, maka dapat ditentukan karakteristik daya kerja mesin pesawat atau panjang landasan yang digunakan untuk take off dan landing. Dalam perhitungan density height perlu diperhatikan batasan-batasan:

1.Suhu atmosfer standar ICAO pada MSL $=15^{\circ} \mathrm{C}$

2.Penurunan suhu terhadap ketinggian pada atmosfer standar $\mathrm{ICAO}=1.98^{\circ} \mathrm{C} / 1000$ feet, harga rata-rata dari density height ini $=120$ feet diatas pressure height untuk selisih suhu sebesar $1{ }^{\circ} \mathrm{C}$ antara suhu sebenarnya dengan suhu pada atmosfer standar ICAO.

\section{Density Height = h'+ (T - Th') x 120 ft}

Dimana :

$\mathrm{h}^{\prime}=(1013.25-\mathrm{P}) \times 28 \mathrm{ft}$

$\mathrm{Th}^{\prime}=15^{\circ} \mathrm{C}-\left(1.98^{\circ} \mathrm{C} / 1000 \mathrm{ft} \times \mathrm{h}^{\prime}\right)$

\section{HASIL DAN PEMBAHASAN}

Dari pengolahan data dengan menggunakan Metode Statistika "Regresi Linear" secara Trend agar dapat diketahui kecenderungan suhu dan tekanan udara setiap tahunnya, dimana data asli (normal) rata-rata periode 1980-2010 dari data temperatur udara maksimum dan tekanan udara diperhalus dengan merata-ratakan kembali data bulanan tersebut menjadi ratarata tahunan. Hasil data yang telah diolah dapat dilihat pada lampiran 1 .

Kemudian data tersebut dibuat kedalam bentuk grafik selama 31 tahun (1980-2010) di Bandara H.A.S. Hananjoeddin Buluh Tumbang Belitung didapatkan hasil sebagai berikut: 


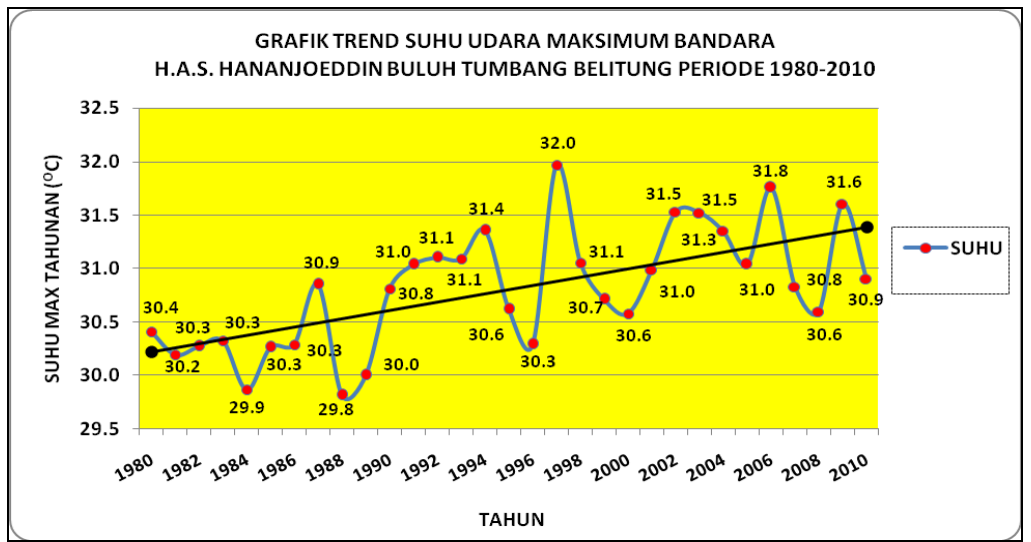

Gambar 1. Trend suhu udara maksimum 1980-2010

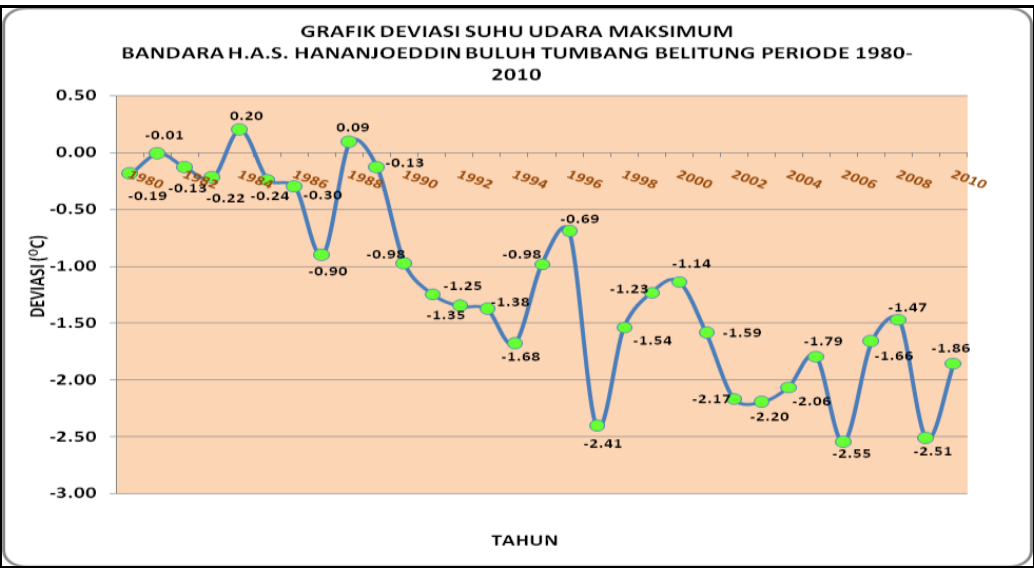

Gambar 2. Deviasi suhu udara maksimum 1980-2010

1. Trend suhu udara maksimum

a. Dilihat dari grafik trend suhu udara selama 31 tahun (1980-2010) trend suhu udara cenderung naik sebesar $1,17^{\circ} \mathrm{C}$.

b. Suhu udara tertinggi dicapai pada tahun 1997 sebesar $31,97^{\circ} \mathrm{C}$.

c. Suhu udara terendah dicapai pada tahun 1988 sebesar $29,82^{\circ} \mathrm{C}$.

d. Deviasi suhu udara tertinggi dicapai pada tahun 2006 sebesar $-2,55^{\circ} \mathrm{C}$.

e. Deviasi suhu udara terendah dicapai pada tahun 1981 sebesar $-0,01^{\circ} \mathrm{C}$.

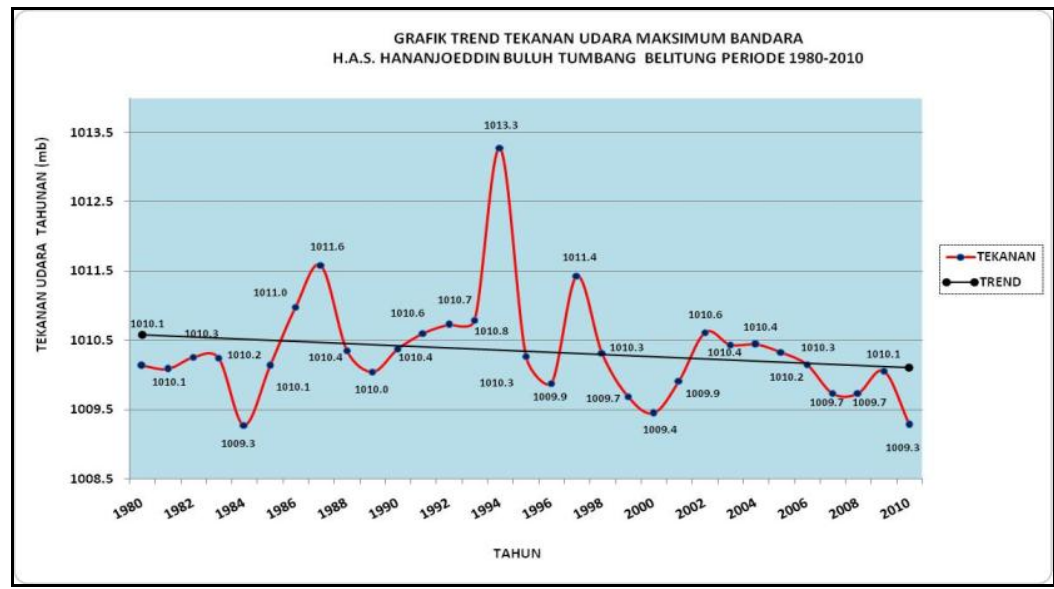

Gambar 3. Trend tekanan udara 1980-2010 


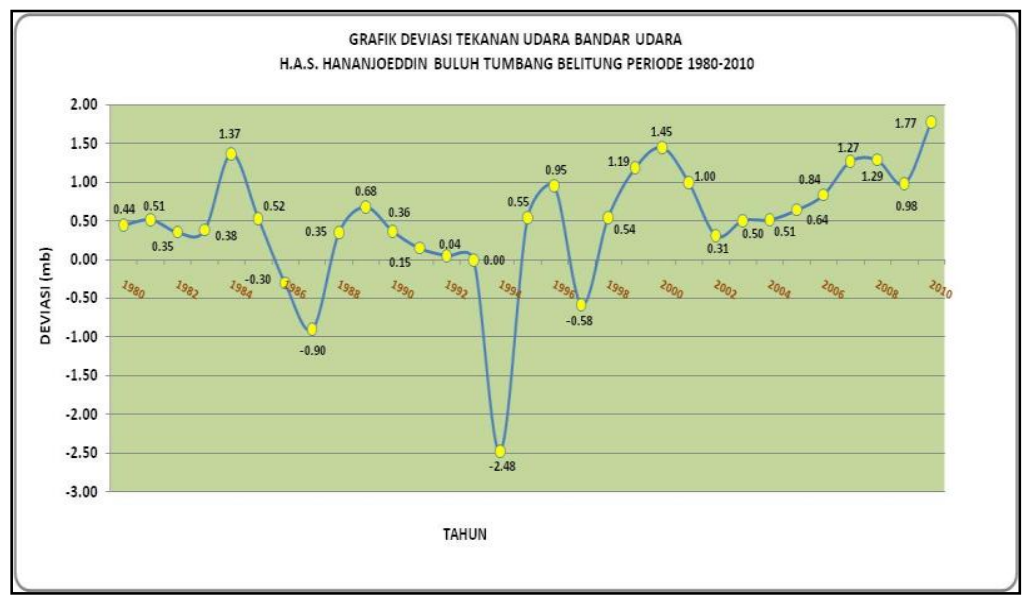

Gambar 4. Deviasi tekanan udara 200-2011

2. Trend tekanan udara

a. Dilihat dari grafik trend tekanan udara selama 31 tahun (1980-2010) trend tekanan udara cenderung turun sebesar $0,47 \mathrm{mb}$.

b. Tekanan udara tertinggi dicapai pada tahun 1994 sebesar 1013,28 mb.

c. Tekanan udara terendah dicapai pada tahun 1984 sebesar 1009,28 mb.

d. Deviasi tekanan udara tertinggi dicapai pada tahun 1994 sebesar -2,48 mb.

e. Deviasi tekanan udara terendah dicapai pada tahun 1993 sebesar 0,00 mb.

Dari analisa diatas, menunjukkan bahwa secara umum kecenderungan atau trend suhu udara turun dan tekanan udara naik setiap tahunnya dari tahun 1980-2010. Sedangkan pada grafik hasil perhitungan dapat diketahui bahwa deviasi antara trend suhu udara dan tekanan udara dengan suhu dan tekanan udara sebenarnya tidak menunjukkan perbedaan yang signifikan sehingga metode regresi linier ini dapat digunakan untuk membuat prakiraan [9].

engan adanya rumus trend tersebut maka penulis mencoba membuat prakiraan suhu udara maksimum rata-rata dan tekanan udara rata-rata tahun 2011 mendatang dengan menggunakan rumus:

1.Prakiraan suhu udara maksimum rata-rata

$$
\mathrm{Y}=30,22233+0,03905 \mathrm{X}
$$

Untuk membuat prakiraan suhu udara maksimum rata-rata tahun 2011, $\mathrm{X}$ menunjukkan tahun ke- 31 dari perhitungan tabel. Sehingga prakiraan suhu udara maksimum didapat:

$$
\begin{aligned}
\mathrm{Y} & =30,22233+0,03905(31) \\
& =30,22233+1,21055 \\
& =31,43385 \\
\mathrm{Y} & =31,43
\end{aligned}
$$

\section{Prakiraan tekanan udara rata-rata}

$$
\mathrm{Y}=1010,5800 \text { - 0,01579X }
$$

Untuk membuat prakiraan tekanan udara rata-rata tahun 2011, $\mathrm{X}$ juga menunjukkan tahun ke-31 dari perhitungan tabel. Sehungga prakiraan tekanan udara didapat: $\mathrm{Y}=1010,5800-0,01579(31)$

$$
\begin{aligned}
& =1010,5800-0,48949 \\
& =1010,09051 \\
Y & =1010,09 \mathrm{mb}
\end{aligned}
$$

Jadi, suhu udara maksimum rata-rata untuk tahun 2011 diprakirakan sekitar $31,43^{\circ} \mathrm{C}$ dan trendnya cenderung naik, sedangkan tekanan udara rata-ratanya diprakirakan sebesar $1010,09 \mathrm{mb}$ dan trendnya cenderung turun.

Pada trend untuk daerah Belitung pada Aerodrome H.A.S. Hananjoeddin Buluh Tumbang memperlihatkan suatu gambaran taksiran temperatur udara rata-rata berkisar antara $29^{\circ} \mathrm{C}$ sampai $31^{\circ} \mathrm{C}$. Dengan kisaran suhu yang demikian tersebut seorang pilot akan lebih menguasai suatu karakteristik lingkungan terutama pada daerah disekitar Aerodrome. Sedangkan trend tekanan udara 
memperlihatkan suatu harga yang berkisar antara $1010 \mathrm{mb}$ - $1012 \mathrm{mb}$. Kisaran tekanan udara yang demikian tersebut akan membantu terutama dalam hal daya angkat pesawat. Jika misalkan tekanan udara pada suatu waktu dapat berubah dari kisaran tersebut, maka kita sudah barang tentu akan mengantisipasi peran kerja dari mesin pesawat terutama untuk lepas landas (take off) dan mendarat (landing ).

\section{Ketinggian Kerapatan Udara (Density Height)}

Density height yang didapat dengan perhitungan dari data tekanan udara (QFE) dan suhu udara yang saling berkaitan akan berpengaruh pada daya kerja mesin pesawat terbang atau panjang landasan yang digunakan untuk take off dan landing.

Dari hasil perhitungan yang dapat, density height terendah pada tahun 1988 dan maksimum tahun 2006, pada saat harga density height mencapai maksimum akan membuat lift (daya angkat) pesawat akan bertambah dan kenaikan suhu akan mengikuti hal tersebut. Tetapi pada saat density height rendah, maka daya angkat pesawat tersebut akan berkurang pula. Hasil perhitungan Density height ini dapat dilihat dari grafik berikut:

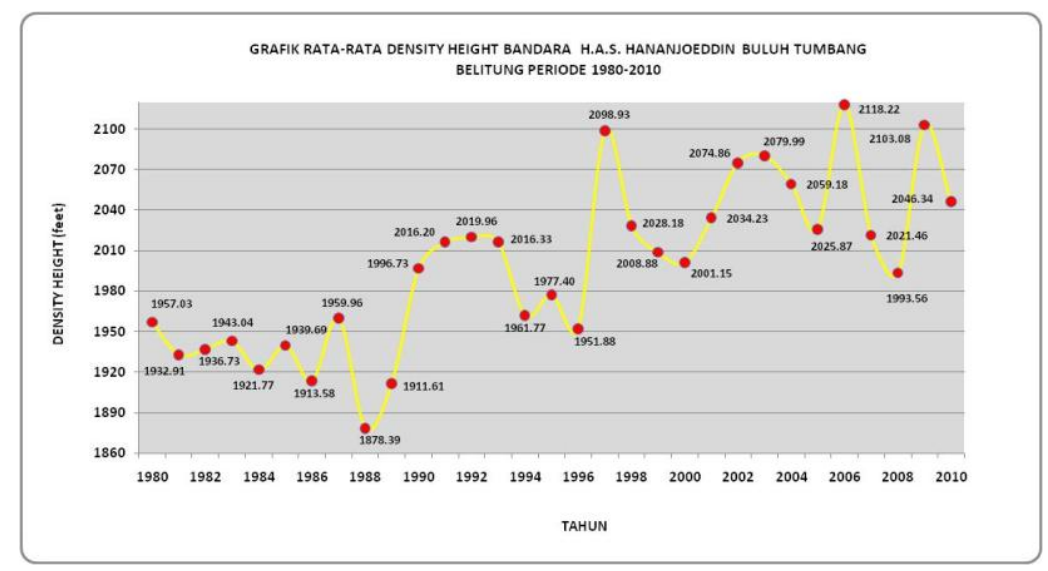

Gambar 5. Rata-rata density height 1980-2010

\section{KESIMPULAN}

Berdasarkan pada uraian pada bab-bab tersebut di atas, maka dapat ditarik beberapa kesimpulan sebagai berikut:

1. Bagi dunia penerbangan pengaruh dari unsur seperti temperatur udara dan tekanan udara sangat berperan terutama pada saat pesawat terbang akan lepas landas (take off) maupun mendarat (landing).

2. Selain unsur-unsur cuaca tersebut penentuan density height (ketinggian kerapatan udara di sekitar Aerodrome perlu mendapat perhatian, karena density height untuk setiap temperatur dan tekanan udara berbeda-beda. Dan juga density height sangat berperan sekali pada daya angkat mesin pesawat terbang pada ketinggian tertentu.

3. Dari hasil perhitungan data suhu udara maksimum dan tekanan udara selama 31 tahun (1980-2010) di Bandara H.A.S. Hananjoeddin Buluh Tumbang Belitung dapat ditarik kesimpulan bahwa trend suhu udara maksimum cenderung turun sebesar $1,17^{\circ} \mathrm{C}$ dan tekanan udara cnderung naik $0,47 \mathrm{mb}$.

4. Garis trend dengan metode "Regresi Linier" dapat digunakan sebagai metode untuk membuat prakiraan. 


\section{DAFTAR PUSTAKA}

[1] Fadholi, A. 2012. Pola Angin Permukaan di Bandara Depati Amir Pangkalpinang Periode Januari 2000 Desember 2011. Jurnal Statistika Universitas Islam Bandung. Vol. 12 No. 1.

[5] Fadholi, A. 2013. Pengaruh Suhu dan Tekanan Udara Terhadap Operasi Penerbangan di Bandara Depati Amir Pangkalpinang. Buletin Balai Besar Meteorologi dan Geofisika Wilayah II Ciputat. Vol. 3 No. 2.

[6] Utama, C. 2008. Pengaruh Suhu dan Tekanan Udara Terhadap Daya Angkat Pesawat di Bandara Hasanuddin Makassar . Skripsi Universitas Negeri Makassar. Makassar.

[2] Soeharsono. 1994. Meteorologi Penerbangan. Balai Diklat Meteorologi dan Geofisika. Jakarta.
[3] Swarinoto, Y. \& Widiastuti, M. 2003. Uji Statistika Terhadap Persamaan Eksperimental Untuk Menghitung Nilai Suhu Udara Permukaan Rata-rata Harian, Jurnal Meteorologi dan Geofisika Vol 3. No.3 Juli-September

[4] Soepangkat. 1994. Pengantar Meteorologi. Badan Diklat Meteorologi dan Geofisika. Jakarta.

[7] Soeyitno dan Soeharsono. 1981. Meterologi Penerbangan . Badan Diklat Meteorologi dan Geofisika. Jakarta.

[8] Soejoeti, Z. 2008. Modul Metode Statistik I (SATS4121). Universitas Terbuka. Jakarta

[9] Hernowo, B. 2002. Diktat Statistika Dasar. Badan Diklat Meteorologi dan Geofisika. Jakarta. 